\title{
電力二次小売システムに基づく分散センサー ネットワークの提案とデータ基盤への利用*
}

\author{
佐藤 彰洋 $\dagger$ ·高木 舞人 $\ddagger$ 長廣 剛 §
}

\author{
Distributed Sensor Network Based on Secondary Retail of \\ Electricity and Usage of Data Management System*
}

Aki-Hiro SATO ${ }^{\dagger}$, Maito TAKAGI ${ }^{\ddagger}$ and Tsuyoshi NAGAHIRO ${ }^{\S}$

This paper proposes decentralized energy management system (DEMS) consisting of center and sensor nodes. The center node has an ability to control sensor nodes which contain sensors and controllers of electricity. We show data on electrical power consumption of Osaka Prefectural Government Sakishima Building (Cosmo tower) located at Osaka Sakishima District. We prototyped a center node and sensor nodes and measure temperature and light strength in Asia Trade Center Building located at Osaka Sakishima District. We propose an indicator of human theremal demand using temperature and light strength measured by the prototype system.

\section{1.はじめに}

先進国の現代社会において社会システムにおけるエネ ルギーの利用状況と経済社会活動との間には密接な関係 が存在している.Fig. 1 は国別の一人当たりの年間電力 使用量 $[\mathrm{kWh}]$ と一人当たり年間国民総生産（2013 年時 点USD）との関係を両対数グラフとして図示したもの である（数值は世界銀行のデータベースサービスのマク ロデータ $[1]$ から得た）。一人当たり年間電力使用量 $E$ と一人当たり国民総生産 $G$ との間にはべき関係

$$
G=C E^{a}
$$

または，

$$
\log _{10} G=a \log _{10} E+\log _{10} C
$$

の関係が存在している。これは生長関係 (allometric relationship) とよばれる [2]. 実線は (2) 式に基づき

* 原稿受付 2013 年 9 月 2 日

†京都大学大学院 情報学研究科 Graduate School of Informatics, Kyoto University; Yoshida-Honmachi, Sakyo ward, Kyoto city, Kyoto 606-8501, JAPAN

‡（株）エナジーシェア／大阪市立大学 工学研究科 Energy share Co. Ltd./Osaka City University

$\S$ (株) Afes /大阪市立大学工学研究科 Afes Co. Ltd./Osaka City University

Key Words: energy, information system, decentralized energy management system, human activity, temperature, light strength.
Reduced Major Axis (RMA) 回帰によって求めた直線 である. べき指数 $a=0.982$ (標準誤差 0.13285 ) と見積 もられる。

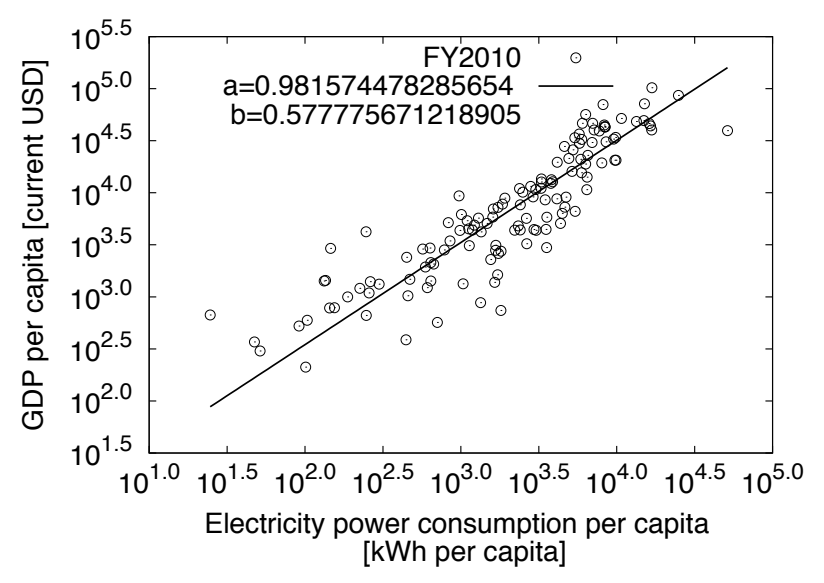

Fig. 1 国別の一人当たりの国民総生産と一人当たりの電力 使用量との関係. 白丸はある国における関係を示す。 算出には世界銀行 DataBank による 2010 年マクロ データをもとにし，両データともに存在する 131 カ 国分データを用いた

先進国の社会システムでは, 輸送や交通, 家電など快 適な生活を実現するために，一人当たりの電力使用量を 増加させ，これが国民総生産から得られる所得とバラン スすることで快適な生活が安定的に持続していると推察 される。そのため，一人当たりの電力使用量を抑制する ことは，利便性を享受できる機会を減少させる結果とな 
りがちである。さらに，化石燃料の消費量抑制（二酸化 炭素の排出量抑制）などエネルギー使用量を減らす努力 が現在求められている。これを実現するためには，現時 点で使用されていない資源や再生可能なエネルギー源の 導入または社会内部の物理的な状態変化を抑制しつつ同 じ効果が得られる情報通信技術 (ICT) の開発と普及が必 須と思われる.

とくに，社会全体でのエネルギー使用量を抑制してい くには, 抑制可能な物理的状態変化の把握と, 人間活動 とエネルギー消費との関係性を詳細に把握することが重 要である。これには，すでに観測可能な物理量から人間 の社会的活動を間接的に把握する方法の開発が有効と考 えられる。たとえば，輸送にかかるエネルギー使用量の 空間的なモニタリングであったり，人間活動の結果付随 的に発生する光や温度変化の観測と空間を考慮したデー 夕統合などが考えられる。

さらに，食料生産と同じ形態での自律分散的なエネル ギー生産 (energy harvesting) を実現し [3]，エネルギー の局所的な生産と消費のための自律分散型のエネルギー 供給消費網を構築する構想が提案されている。ここでも， 人間活動の大域的な把握は重要な技術となっている。ま た, 太陽光発電や風力発電をはじめとする再生可能エネ ルギーの普及のみならず，新しい技術の研究開発も進め られている $[4]$.

一方，人間の社会的活動に関する研究が活発に行われ ている. Crowd Dynamics の研究では, 駅などの人の流 れをビデオカメラで撮影し半自動的に移動の軌跡を抽出 できる技術が開発されている $[5]$. さらにビデオカメラに よるモニタリングと数值シミュレーションとを統合する ことにより空間内での人の密度の時間変化をとらえたり 予測したりすることが可能となっている $[6]$. 携带電話の 位置情報を利用することによってもリアルタイムに近い 形で人の移動を抽出することができる [7].

一方，エネルギーの使用状況を把握するために，エネ ルギーマネジメントシステム $(\mathrm{EMS})$ が導入されるよう になってきた。 とくに，インターネットを利用してセン サーネットワークから収集されるデータを位置情報とあ わせてリアルタイムで集めることで使用電力を減らすた めの行動を支援する体制が整いつつある。たとえば，東 京大学本郷キャンパスでの電力の見える化の事例 [8] やビ ルメンテナンス会社による電力見える化サービス $[9]$ が 実用化されつつある。 さらに，サイバーフィジカルシス テム (Cyber Physical System)[10]の文脈においてセン サーネットワークからの情報に基づくスマートグリッド の制御方法と安定性に関する研究が存在している $[11,12]$.

ここで，技術的に可能な仕組みを組み合わせつつ，計 測すべき範囲を広くとれるようにするためには，電力七 ンサーの組込みを可能とする機器の普及を後押しできる 社会システムと組み合わせることが有効であると考える.
本研究では分散型エネルギーマネジメントシステム を普及させるための方向性として, 電力二次小売システ ムを構築することを通じてセンサーネットワークを構築 する方法について議論する。本研究は環境省地球温暖化 対策技術実証事業「鉄道路線を利用した地域融通エネル ギーシステム構築技術の研究開発」に基づき開発したシ ステムのプロトタイプを用いて計測をおこなった。さら に，大阪市咲洲地区での実証実験で得られた測定結果に ついて報告する。最後に，分散型エネルギーマネジメン トシステムとこれにより構築されたセンサーネットワー クの自然災害などによる大規模停電時の利活用について 議論する。

\section{2. 電力使用量の実証分析}

大阪府咲洲庁舎の場合，地域冷暖房を熱源とするレン タブル $60 \%$ 以上のテナントビルの延べ床面積と年間総エ ネルギー消費量の相関関係によると $2\left[\mathrm{GJ} /\right.$ year $\left./ \mathrm{m}^{2}\right]$ が 標準的な值である。年間総エネルギー消費量は約 26 億 [GJ/year] と推計される.

さらに，ビル内での施設利用状況と対応してビル全体 のエネルギー使用量は大きく変化している. Fig. 2 は大 阪市咲洲地区にある大阪府咲洲庁舎の 2011 年 4 月 11 日 の 30 分ごとの 1 日間の電力使用量 (a) と 2011 年 4 月 1 日から 11 月 30 日までの 30 分ごとの電力使用量 (b) と を示したものである. Fig. 2(a) から, 施設の使用が活 発となる午前中から夕方までの間に電力使用量のピーク が存在していることが読みとれる。 さらに，夕方から夜 間にかけて電力使用量は少ない.

Fig. 2(b)より電力使用量は単調な変化をしておらず カレンダーの日時と連動した季節変動が存在しているこ とがわかる。この季節変動の多くは施設の利用状況を大 きく反映していると考えられる。大阪府咲洲庁舎ではほ ぼ無人となる深夜時間帯においても 30 分当たり $400 \mathrm{kWh}$ 程度の電力量を使用しておりピーク時には 30 分当たり 2000kWhの電力量を消費している.

標準的な事務所ビルで延べ床面積あたりでの電力使用 量 (電力使用量密度) の值を Table 1 に示す. この電力使 用量密度は参考文献 [16] に基づく.この值はレンタブル に依存するが大阪府咲洲庁舎の場合にあてはめると大阪 府咲洲庁舎の延べ床面積は $149,296 \mathrm{~m}^{2}$ なので, 平日昼間 で $3,732 \mathrm{~kW}-4,478 \mathrm{~kW}$, 平日夜間で $1,045 \mathrm{~kW}-1,194 \mathrm{~kW}$ となる。さらに，オフィスビルにおける年間総エネル ギー消費量はビルの延べ床面積にほぼ比例することが 知られている. 大阪府咲洲庁舎においてはこのうちに夏 季の最大冷房負荷は $392 \mathrm{~W} / \mathrm{m}^{2}$, 冬季の最大暖房負荷は $251 \mathrm{~W} / \mathrm{m}^{2}$ と見積もられるが大阪府咲洲庁舎の場合地域 冷暖房を利用しているため電力使用量に熱負荷が含まれ ない. そのため, この深夜時間帯における電力使用量は Table 1 で示した夜間における標準的なオフィスビルの 夜間深夜電力使用量密度から計算される範囲内であり特 
段大きな值というわけではない.また，2011年 10 月以 降大阪府咲洲庁舎内のテナントやホテルの閉店に伴い ピーク時の電力使用量が減少していく様子を読み取るこ とができる。
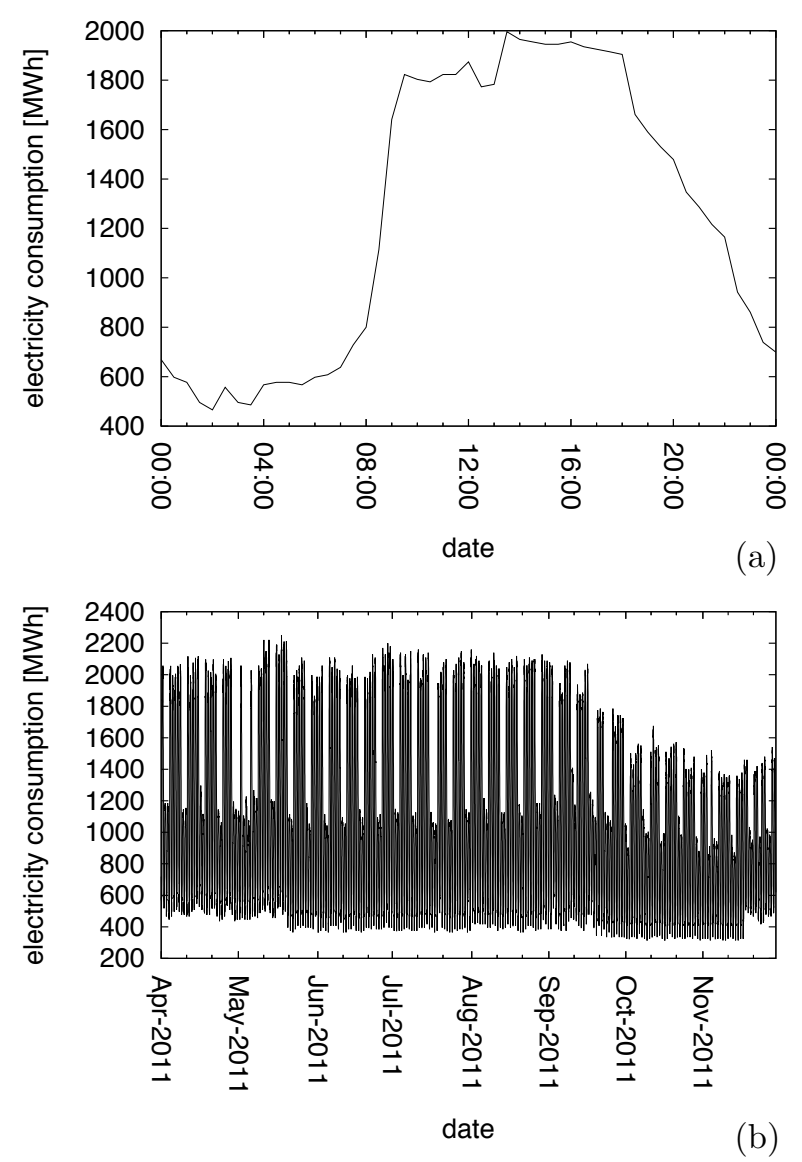

Fig. 2 大阪市咲洲地区大阪府咲洲庁舎における 2011 年 4 月 11 日の 30 分ごとの電力使用量 $[\mathrm{kWh}](\mathrm{a})$, および 2011 年 4 月 1 日から 11 月 30 日までの 30 分ごとの 電力使用量 $[\mathrm{kWh}](\mathrm{b})$.

Table 1 オフィスビルにおける標準的な電力使用量の值

\begin{tabular}{ll}
\hline 平日昼間 $(10$ 時 17 時 $)$ & $25-30 \mathrm{~W} / \mathrm{m}^{2}$ \\
平日深夜 $(0$ 時 $~ 5$ 時 $)$ & $7-8 \mathrm{~W} / \mathrm{m}^{2}$ \\
休日昼間 $(10$ 時 $~ 17$ 時 $)$ & $8-12 \mathrm{~W} / \mathrm{m}^{2}$ \\
休日夜間 (0 時 $~ 5$ 時) & $6-8 \mathrm{~W} / \mathrm{m}^{2}$ \\
\hline
\end{tabular}

\section{3. 単純なエージェントモデルによる解釈}

1.の Fig. 1 で用いた世界銀行のデータベースサービ ス DataBank[1] によると，日本における一人当たりの 電力使用量と一人当たりの GDP は, 2011 年 1 年間にお いてそれぞれ 45,902.671[USD], 7,847.80[kWh]である. このことから，2011年の 1 時間当たりの単位人当たり の GDP と単位人当たりの電力量はそれぞれ 5.24 [USD], 918.52[Wh] と計算される.
ある建物において時刻 $t$ における 1 時間当たりの総電 力使用量を $V(t)$, その建物内で活動しているエージェン トの人数を $N(t)$ とする. 平均的に建物におけるエージェ ントの 1 時間当たりの電力使用量は一定の值をとり一人 当たり 918.52[Wh] であると仮定する．空調については 外気温や日照条件により電力使用量に差異があることは 明らかであるが, このことを考慮したい場合には $k_{1}$ が 季節の関数となる。ここでは, 季節性は単純化のため考 慮しないとする。このとき,

$$
V(t)=k_{1} N(t)
$$

の関係が成立すると仮定する。ここで， $k_{1}=918.52$ [Wh/h/person] である。これより $V(t)$ を所与とした ときにその建物内で活動するエージェント数 $N(t)$ は

$$
N(t)=\frac{V(t)}{k_{1}}
$$

と求められる。ささに 1 時間当たりの建物内で活動を 開始した人数 $N_{+}(t)$ と活動を終了した人数 $N_{-}(t)$ の 差 $\Delta N(t)$ は $N(t+1)=N(t)+\Delta N(t)$ より $\Delta N(t)=$ $N(t+1)-N(t)$ となる. これより, $V(t)$ が所与の場合

$$
\Delta N(t)=\frac{V(t+1)-V(t)}{k_{1}}
$$

として 1 時間当たりの建物内で活動を開始したエージェ ントと終了したエージェントとの差異を推定することが 可能である. さらに, 建物内で生み出される 1 時間当た りの GDP, $G(t)[\mathrm{USD} / \mathrm{h} /$ person] は (4) 式を用いること により

$$
G(t)=k_{2} N(t)=\frac{k_{2}}{k_{1}} V(t)
$$

と見積もられる。ここで $k_{2}=5.24[\mathrm{USD} /$ person] である. よって $k_{2} / k_{1}=5.7048[\mathrm{USD} / \mathrm{kWh}]$ である.

実際に大阪市咲洲地区の大阪府咲洲庁舎での 1 時間当 たりの電力使用量を用いてどの程度の人数が建物内で電 力を使用しているかを推計してみる. Fig. 3 は 2011 年 4 月 1 日から 2011 年 11 月 31 日までの推計である. 最大 で 600 人/hour の建物内部での電力を消費する活動を開 始しており，一方で 400 人/hour が電力を消費する活動 を止める様子を見ることができる．Fig. 4 は 2011 年 4 月 12 日における 1 日の間での $\Delta N(t)$ の推計值である. これを見ると活動は午前 6 時頃から徐々に電力を建物内 部で使い始め, 午前 9 時頃に 500 人/hour が電力を使い 始めている。ささらに，12 時半にいったん電力使用を 100 人/hour 程度が止め再び午後 1 時半から 200 人/hour 程 度が電力を使用し始めている. 午後 6 時に 250 人/hour が電力の使用を終える人が増え午後 11 時半頃まで 100 人/hour 程度の人が電力使用を止めている. 電力使用を 始める午前 9 時頃は仕事開始の時間であり，お昼休みの 午前 12 時半に電力使用を止め, 午後 1 時半にお昼休み 
が終わり仕事に戻り, 午後 6 時から午後 11 時半にかけて 仕事を終えて帰宅していく様子とこの活動パターンはよ く符合する。

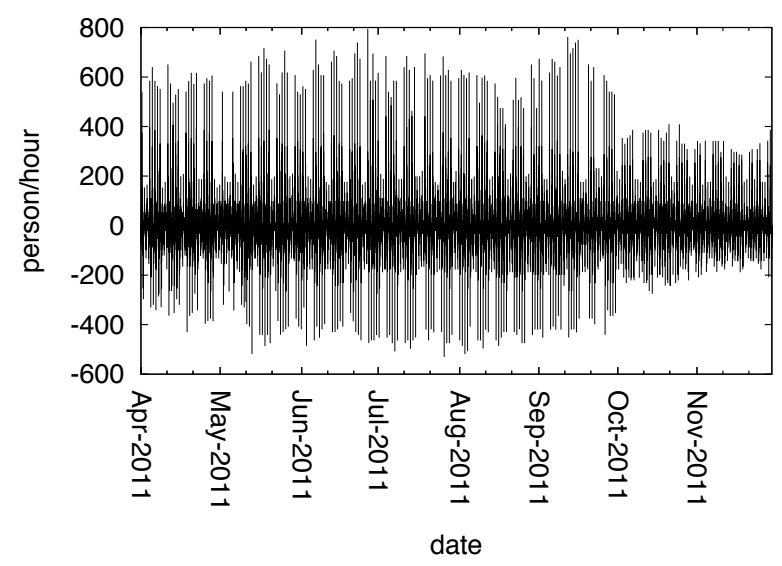

Fig. 32011 年 4 月 1 日から 2011 年 11 月 31 日までの大阪 市咲洲地区大阪府咲洲庁舎の電力使用量から推計さ れるエージェントの出入り。

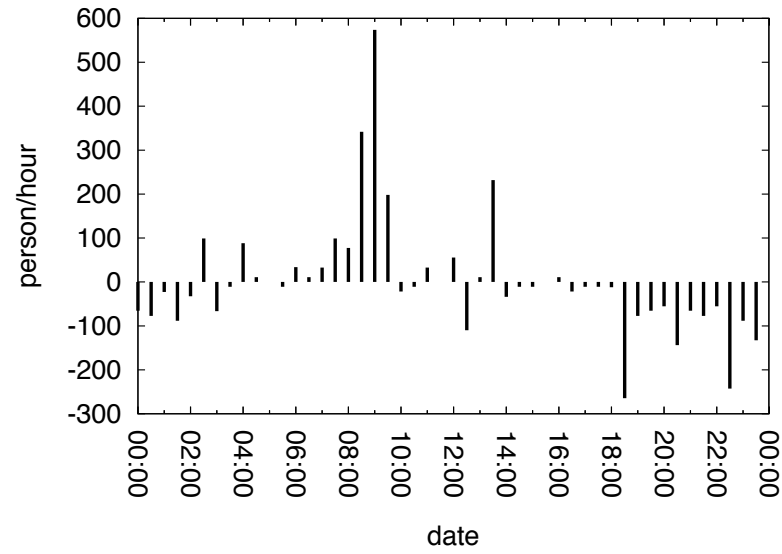

Fig. 42011 年 4 月 12 日の大阪市咲洲地区大阪府咲洲庁舎 の電力使用量から推計される 30 分ごとのエージェン トの出入り.

\section{4. 電力使用量の実証分析}

付録 1. で正規分布モデルに従う時系列分割方法を示 す.この方法は時系列の各断片が平均值と分散值が異な る正規分布からの抽出であると仮定し，平均值と分散值 の異なる正規分布の混合モデルと単一の正規分布モデル との間で尤度比検定を行い時系列の分割の有無と分割点 を決定する方法である.

この時系列分割方法を Fig. 2 で示した大阪府咲洲庁 舎の電力使用量（2011年 4 月 1 日から 11 月 30 日）の時 系列に適用する。Fig. 5 は，2011年 4 月 1 日から 11 月 30 日までの 30 分ごとの大阪府咲洲庁舎全体での電力使 用量を $\Delta_{c}=10$ として分割したときの分割箇所を示して いる．この分割方法によって複数の性質の異なるセグメ ントを抽出することができた。 とくに，春の時期と，夏

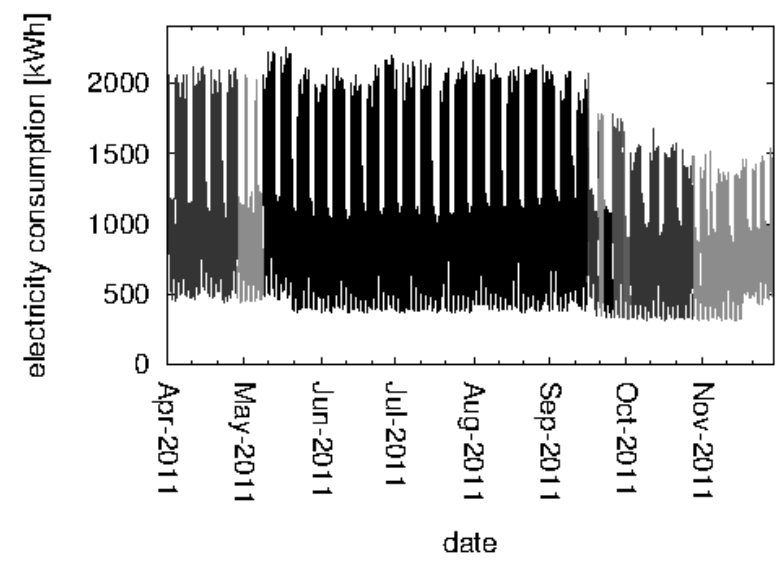

Fig. 5 大阪市咲洲地区の大阪府咲洲庁舎に扔ける 2011 年 4 月 1 日から 11 月 30 日までの 30 分ごとの電力使用 量 $[\mathrm{kWh}]$ の差 $\Delta V(t)=V(t+1)-V(t)$ について時 系列分割方法を適用し，この分割箇所を $V(t)$ につい て図示したときの分断䇢所 $\left(\Delta_{c}=10\right)$. 各色の違い は分割箇所の違いを示している。

の空調利用が活発となる時期の分割がなされている. 分 割を決める有意水準は $\Delta_{c}$ の值が決めているためこの值 を変化させることにより, 異なる解像度での分割が可能 である。

人間活動は定常時系列ではなく局所定常時系列の結合 による非定常時系列であるとみなすことにより，その変 化の様子をとらえることが可能であると予想される。こ のような非定常性は建物の中での人間の活動が一定では ないことの所産であるが，全体的な観点からの電力使用 量の把握だけでは建物内のそれぞれの場所においての電 力と温度の両面からエネルギーマネジメントを行うには 情報が不足している。この不足する情報を補うためには より利用者に近い場所でエネルギーの使用状況を把握し， エネルギー使用量を調整する必要があると思われる。

\section{5. 社会システムとスマートグリッド}

現存する経済・社会システムに扔けるネットワーク構 造は局所観測による部分情報しかもたない多くのエー ジェントが, 局所での最適性を考慮した結合戦略の結果, 進化的に形成されてきたものである [13]. 近年のネット ワークシステムに対する研究によると, 要素間の結合密 度の増加はシステム全体を停止させる確率の増加をもた らすことが認識されている [14]。これはシステミックリ スクとよばれ，多くの素子との間で関係が深まれば深ま るほどにシステム全体が停止する確率（脆弱性）が逆に 増加することを示している。

ネットワーク結合密度が高まり過ぎた体系に対しては, 逆にネットワーク間の結合を弱めることが体系全体での システミックリスクを下げることにつながる [13].

既存の電力系統はエージェント間の局所観測と最適化 戦略の繰り返しによって発展的に作られてきた歴史的 
経緯をもっている，そのため，既存の電力系統に対して ネットワーク間の結合を弱めることは得策ではない。こ れに似た効果をもたらす方法としては, 既存電力系統の 送電網とは独立に，電力供給を局所的に行うことができ る小さくかつ安価なシステムの社会への普及が考えられ る. すなわち, 通常の電力系統による電力供給がなくて も，自律的に使用者に電力を供給することができるよう な補助装置の普及である.

実際，このような小型の電力供給システムはすでに家 庭用，商業用，レジャー用として小型の発電機，太陽光 発電システム, ガスヒートポンプ, 充電池の形で実用化 されてきている。さらにこれらを高度化した，“スマー トグリッド”とよばれるシステムの普及が推進されてい る.これは, 出力が天候に依存する風力発電や太陽光発 電, 需要家により自由に使用される電気自動車やヒート ポンプ給湯器などの需要家機器を, 大容量蓄電池や制御 可能な分散型電源とともに双方向情報通信ネットワーク を利用して統合的に制御を行うことによって，系統に発 生する問題を解決し, 高信頼度, 高品質の電力供給を行 う仕組みである $[15]$.

このような自律型の電力源が分散配置された社会シス テムにおいては，あるトリガーとなる過酷事象が発生し た場合, 組織の構成員が自活し, システムの復旧に備え ることができると期待される．大規模停電への備えのた めに自立型電源を用いる場合, 現存の電力系統に接続し 複雑な制御装置を介して負荷分散を行うことをしなくて も社会システムの強化に十分役立ちうる。現在，家庭用 やオフィス用に普及しつつあるスマートグリッドの要素 技術を安価にかつ単純化することが普及の鍵となるはず である。

\section{6. 電力小売の自由化}

現在電力小売の完全自由化に関する議論が国内で進め られている. 2013 年現在, 一般家庭などの電気使用者を 除き特定規模電気事業者（いわゆる新電力）による電力 の小売自由化が施行されている。これは，1995年から始 まった第一次制度改革の延長線上にあり，契約電力が段 階的に引き下げられていった結果である。 2013 年現在, 契約電力 $50 \mathrm{~kW}$ 以上の高圧需要家までが自由化対象とさ れている。

経済産業省資源エネルギー庁「電力小売市場の自由化 について」の資料によると [17]，小売自由化を開始して 以降の新電力数は増加してきており，2012 年 3 月末時点 で 53 社が特定規模電気事業者としての届出を行ってい る。このうち 2012 年 1 月現在で実際に自由化分野での電 力供給を行っているのは 27 社である. 実際の新電力に よる電力供給は 2010 年現在 $3.47 \%$ である。今後, さら に契約電力の引下げが議論されており，2016 年頃には家 庭用一般電灯契約においても小売自由化の検討が始まっ ている.
このように, 電力の小売自由化は大規模特定電力に限 定されている状況である. しかしながら, もし発電と送 電の分離が今後進み, 電力の二次小売を容易とする方法 が確立したとするならば，新電力による電力の供給シェ アは増加する可能性がある。この分野では技術革新の可 能性が予感されている [18-20].

次節では，スマートタップを利用した電力二次小売シ ステムについて議論し，このシステムを核とすることに よる分散型のエネルギーマネジメントシステムとセン サーネットワークの可能性について言及する.

\section{7. 電力二次小売システム}

\section{1 仕様}

ここで提案する電力の二次小売システムはオフィスビ ルや商業施設内の店舗に設置可能なセンサーノード（ス マートセンサータップ) と, センターノード (EMS) か ら構成されている。これによって商用系統や自家発電装 置, 自然再生エネルギー源から供給される電力と熱を利 用できるようにし，さらに課金を可能とすることにより， 小売システムを構築することを目的とする.

センサーノードとセンターノードとの間の通信には電 力線通信 $(\mathrm{PLC})$ を用いる. 各センサータップにはセン サー部があり，環境およびユーザーの電力使用状況をセ ンターノードから遠隔でモニターすることが可能である. さらに，センターノードに集められたユーザーデータお よび環境データはデータセンターにインターネット経由 で暗号化された安全な形で送信できる仕組みを想定する。

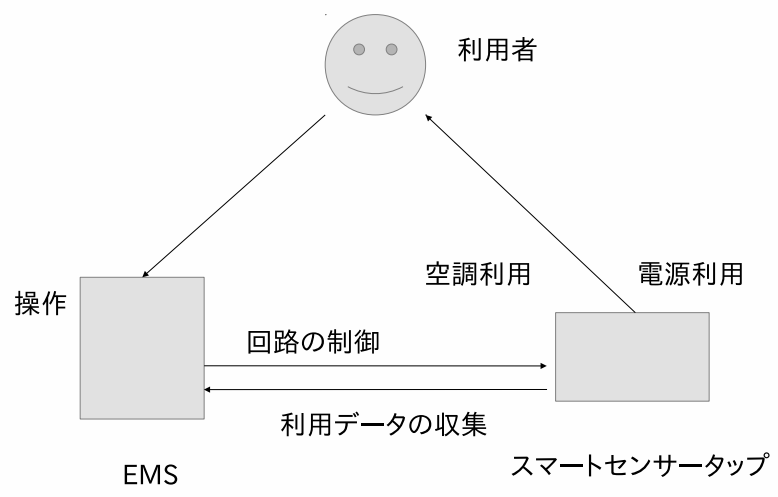

Fig. 6 電力二次小売システムの利用形態

Fig. 6 は電力二次小売システムで仮定される利用の様 子である. EMSに接続されたコントローラを用いて電 力二次小売事業者は利用者に EMS 経由で電源と空調の 利用を可能とする権限を付与する。 利用者の使用履歴は EMS 経由でデータクラウドへ送信される。 さらに顧客 の熱と電源利用履歴から, 利用時間や利用形態に応じて 代金請求を行う。この仕組みをオフィスビルや商業施設 で普及させることにより, 電力二次小売網を形成すると 
ともに，環境と人間活動に関るデータインフラストラク チャーの構築を目指す.

さらに，自然災害発生時における停電時には商用系統 から解列して単独運転へ以降する仕組みと, 停電解消時 には商用電源と連携して単独モードから商用系統へ並列 するための仕組みが必要である。この仕組みを組み入れ るためには EMS とスマートセンサータップがルーティ ング機能およびバッテリーバックアップ機能を有する必 要がある。

\section{2 プロトタイプ}

電力二次小売システムの概念を Fig. 7(a) に示す. 提 案するシステムはスマートセンサータップ（センサー ノード）と EMS（センターノード）とをスター型に接続 し，各 EMS データクラウドと逐次通信を行いデータク ラウド上にEMS で蓄積されたデータを送信する仕組み となっている. Fig. 7(b) に示すように，センターノー ドおよびセンサーノードはファイアウォール $(\mathrm{FW})$ 内に 設置され，EMS とスマートセンサータップとの間との 通信は，PLC(Power Line Communication)を介して行 われる。これにより，家庭内やオフィス内に新しくネッ トワーク網を構築することなく, コンセントに必要な機 器を接続するだけで EMS の内部ネットワークが構築さ れる仕組みとなっている.

これを実現するために PLCアダプターを介してイー サーネットネットワークを構築し，このネットワーク上 に配置されたスマートセンサータップをEMS から制御 することにより，スマートセンサータップからデータの 収集, 演算機能, スマートセンサータップにおける電源 開閉の実装を行った。

センサーネットワーク構築のための基礎技術として Arduino UNO のデジタル入出力を用いたネットワーク 制御のためのセンサー, ソードの構築と, 制御・デー 夕収集サーバーの試作，および，これらを用いた基礎 データの収集実験を行った。センサーネットワークは Arduino UNO とイーサーネットシールドを用いこれを 10Base-TXのハブを経由して制御・データ収集を行う EMS と接続する構成とした (Fig. 7(b) 参照). Arduino UNO 側では二つのデジタル出力 $(256$ 階調 $)$ と一つのア ナログ入力（1024階調）を設定し（増設可能），500ms に 1 度の割合で割り込みを入れアナログセンサーの状 態をサンプルし内部メモリに記憶する仕組みとした。 Arduino UNO 側にはひとつずつIPアドレスと MACア ドレスが割り当てられており，センターノードが提供す る NTP(Network Time Protocol) サーバーと UDP 通 信を行うことにより内部クロックの同期を 5 分間隔に 行う構成となっている. 制御・デー夕収集に用いられる EMS は各センサーノード (Arduino UNO) との通信ご とに子プロセスを生成し，並列処理的にデータ収集・制 御信号送信を行うことができるよう設計を行った。これ

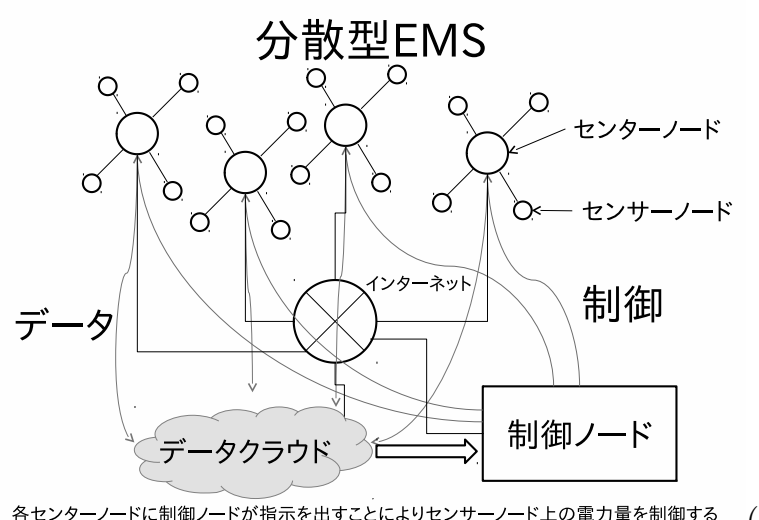

(a)

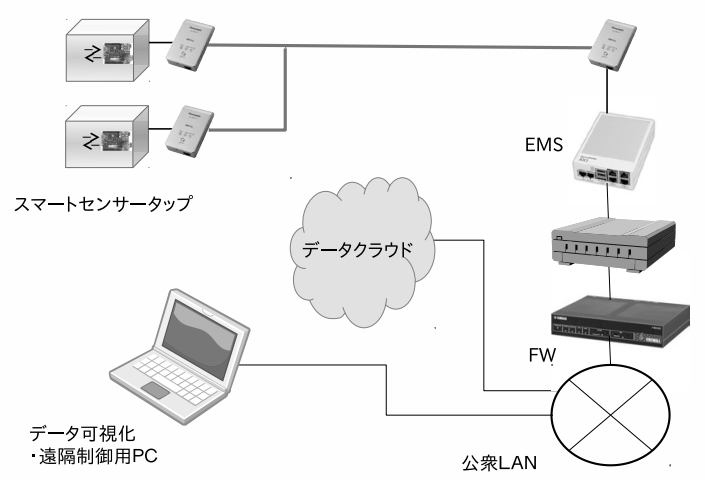

(b)
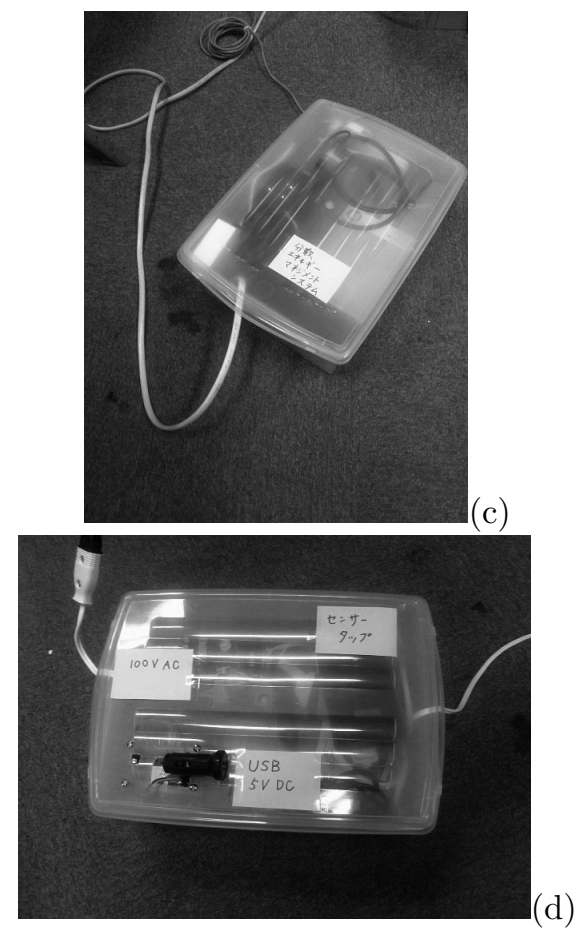

Fig. 7 (a) 分散型 EMS の模式図. (b) 実験システムの模式 図. (c) センターノード (EMS). (d) センサーノード (スマートセンサータップ).

はセンサーノード要素数と制御点が増加した場合におい てもセンサーノードからのデータ収集と制御に遅延が発 生しないための工夫である。

センターノードからの制御信号により，二つのセン 
サーノードにある二つのデジタル出力に対して $5 \mathrm{~V}$ 直流 (USB) と $100 \mathrm{~V}$ 交流の電力供給を指定時間中提供するこ とができる．電力供給を行うコンセントに接続されたス イッチの開閉時間をセンターノードから指定できる仕様 とした。ささらに，5分おきにセンターノードはセンサー ノードからアナログ入力に取り付けられた温度計と光量 計から室内の温度（摂氏温度の 10 倍）および光量值を 1024 階調（0は暗い，1023は明るいことを表す）で収集 し蓄積する。

Fig. 7(d) は試作を行ったスマートセンサータップで ある．複数台のセンサーノードから集められた照度と温 度を $\mathrm{EMS}$ 上のデータベースサーバに記録しつつ, EMS 上から直流 $5 \mathrm{~V}$ と交流 $100 \mathrm{~V}$ のコンセントの開閉が可能 な仕組みとなっている。 これにより, 電力二次小売を行 う場合に, 顧客への電力供給を事業者が遠隔で行うこと が可能となる。

\section{3 測定結果}

大阪市咲洲地区において，電気と熱の広範囲における 分散的な提供を可能とするセンサーネットワークおよび 制御装置の開発を目指しプロジェクトが実施されている. このプロジェクトの一環として，大阪市咲洲地区の 4 施 設のうち商業施設であるアジア太平洋トレードセンター の ITM 棟において電力二次小売システムの構築実験を 行った. Fig. 8 はITM棟全体で冷房用冷媒として使用さ れている冷水還温度 $(\mathrm{a})$ と電力使用量 $(\mathrm{b})$ との曜日ごと の日内変化を 24 時間ごとに図示したものである。デー夕 は 2013 年 7 月 9 日から 2013 年 8 月 3 日までの 1 時間ご との測定值である。これを見ると午前 8 時ごろから徐々 に建物全体で冷房が利用され始め, 午後 8 時ごろに利用 が終えられていることがわかる。電力についてもほぼ同 様であり深夜帯に $400 \mathrm{kWh} / \mathrm{h}$ の電力使用量であったも のが午前 8 時ごろから徐々に上昇し，日中 $1,800 \mathrm{kWh} / \mathrm{h}$ 程度が利用されている。これは午後 6 時ごろから減少し はじめ午後 10 時以降はほほ $400 \mathrm{kWh} / \mathrm{h}$ の使用量となる. このことから建物全体での空調と電力の利用状況は相関 していることがわかる. しかしながら，建物の個別の場 所においてどのような空調と電力の利用がなされている かについてはどのようになっているのであろうか. この ことを調べるために，スマートセンサータップ試作機を ITM 棟内のオフィスに設置して状況を調べた.

Fig. 9 は試作機を用いて大阪市咲洲地区アジア太平洋 トレードセンターITM 棟内のオフィスに設置したセン サーノードから収集された温度と照度に対応する 1024 階調のデジタル值の時系列である. Fig. 9(a) は曜日ごと の 24 時間での温度に対応する 1024 階調のデジタル值の 変化を示している。 デジタル值 $\times 0.1$ が摂氏温度と対応 している. Fig. 9(b) は曜日ごとの 24 時間での照度に対 応する 1024 階調のデジタル值を示している，值が大き い場合は明るく值が小さい場合は暗いことに対応する.
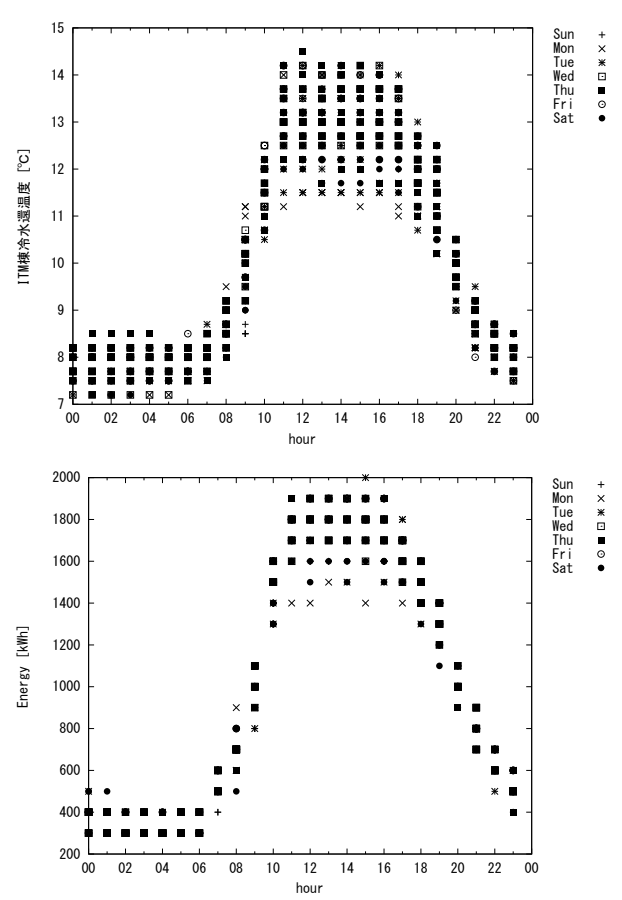

(a)

Fig. 8 曜日ごとの (a) 空調用冷水還温度と (b)ITM 棟全体 での電力使用量の 24 時間ごとの時間帯プロット. 点 の違いは曜日の違いを示している.

1023 以上に対応する照度の場合は值が飽和する性質をも つ。データは 2013 年 7 月 9 日から 2013 年 8 月 3 日まで 5 分間隔で収集した（データ点数は $N=5,953$ である）。 この計測位置においては午前 8 時頃から午後 10 時頃ま での間で室内温度が摂氏 26 度前後に維持されることが わかる。ささらにこの間照度が上昇している。これは Fig. 8 に示した建物全体の傾向と類似した動きである.

室温と照度との相関関係を定量化するためにスピアマ ンの順位相関係数を導入する。 $i$ 時間における温度 $X_{i}$ と 照度 $Y_{i}$ の測定值の順位の差を $D\left(X_{i}, Y_{i}\right)$ とすると, 順位 相関係数は

$$
\rho=1-\frac{6 \sum_{i=1}^{n} D\left(X_{i}, Y_{i}\right)^{2}}{N^{3}-N}
$$

と定義される。Fig. 9 に示した観測データの温度と照 度とのスピアマンの順位相関係数は- 0.757 となり照度 と温度との間には強い反相関が存在することがわかる. これは，夏場にオフィスで人が活動している場合には冷 房を利用するため温度が下がる傾向にあることを示唆し ている，不在時にはオフィスの室内温度が上昇している ことによる。また，オフィスに利用者がいる（これはオ フィスで人が活動する）場合，一般に照明を利用するた め，利用者がいる場合には照度が高くなる，そのため， 室内温度と照度との間には反相関があるように見える。 この室内温度と照度との間に見られる負の相関関係を仮 定することにより人の存在と活動の様子を複合的に計測 することが可能である.

順位相関係数の值が負となったのはこの計測期間が夏 


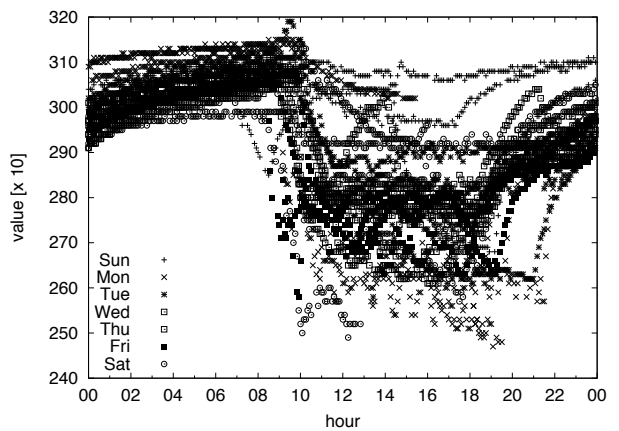

(a)

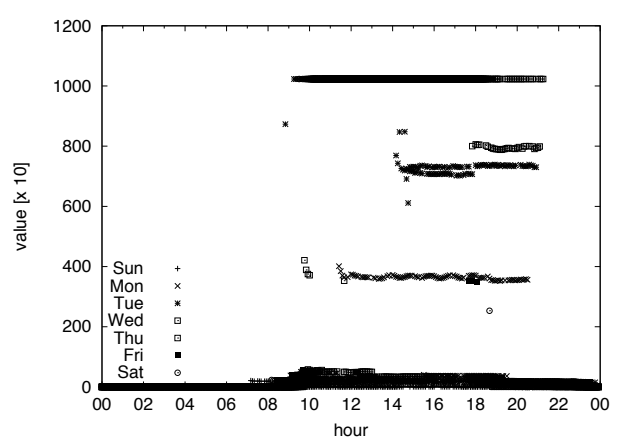

(b)

Fig. 9 曜日ごとの (a) 室内温度と (b) 照度の 24 時間での時 系列. (a) 温度に対応する 1024 階調のデジタル值を 示し，デジタル值 $\times 0.1$ が摂氏温度と対応している. (b) 照度に対応する 1024 階調のデジタル值を示して いる，值が大きい場合は明るく值が小さい場合は暗 いことに対応する。1023以上に対応する照度の場合 は值が飽和する性質をもつ。

場であったため冷房を利用するからである．冬場では逆 に在室時は暖房を利用するためスピアマンの順位相関係 数は正の值となる．春や秋など空調をあまり必要しない 場合においては $\rho$ は 0 近傍となる。このことから温度 $X_{i}$ と照度 $Y_{i}$ との間のスピアマン順位相関係数 $\rho$ は在室中の 人の熱需要に対する代表量として利用できる.

Fig. 10 は 2013 年 7 月 13 日土曜日から 18 日水曜日ま での 6 日間の室内温度 $(\mathrm{a})$ と照度 (b) である（7月 15 日 月曜日は海の日であり国民の祝日である）。計測を行っ た部屋は典型的なオフィスフロアであり室内温度の制御 と照明の点灯は個別に設定できるが，空気の温度は拡散 していくためフロア内の他の室内設定温度に強く影響を 受ける。一方照度は若干影響を受けるものの計測地点近 傍の影響に留まる傾向がある，室内温度は人間の活動時 間で低下しほぼ一定となる。これは空調の設定温度にほ ぼ温度が調整されるからである。1 13 日から 15 日は測定 点付近で照明を使用していない，空調はほぼ一定に保た れている時間帯があることからフロア内の別の地点で人 の活動があったものと考えられる。16日と 17 日は計測 点近傍で照明が利用されており，これが飽和として確認 される。

空調（熱）と電力の利用の両方をとらえることにより 人の活動をより空間的にとらえることができると考える. 今後, 電力二次小売システムから収集されるデータを位

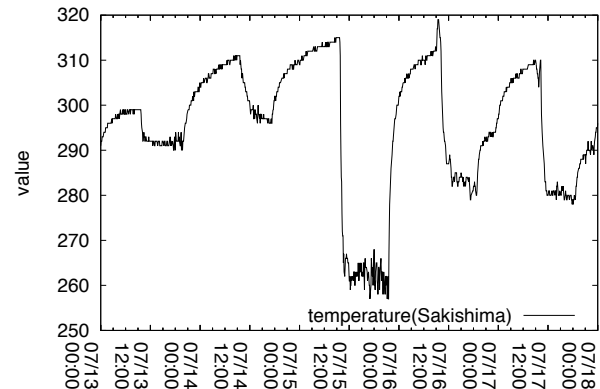

date

(a)

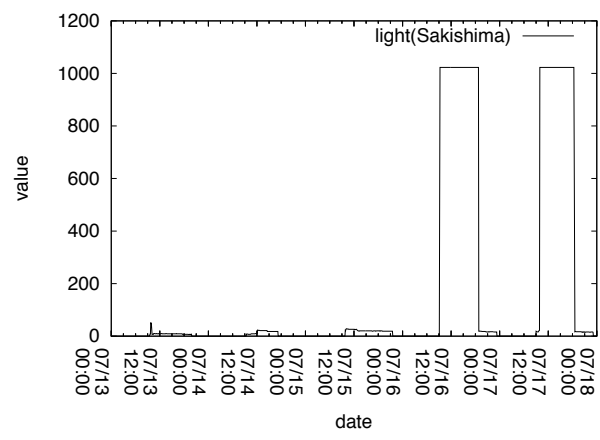

(b)

Fig. 102013 年 7 月 15 日から 18 日までの (a) 室内温度と (b) 照度の時系列. (a) 温度に対応する 1024 階調の デジタル值を示し，デジタル值 $\times 0.1$ が摂氏温度と 対応している。 (b) 照度に対応する 1024 階調のデ ジタル值を示している，值が大きい場合は明るく值 が小さい場合は暗いことに対応する。1023 以上に 対応する照度の場合は值が飽和する性質をもつ。

置情報と統合することで, 空間中の人間活動の様子を匿 名化しつつ建物内の人の動きをリアルタイムで把握する ことを目指す。このとき，建物あるいは空間全体にわた り収集されたデー夕を統計処理することで個人が特定で きないデータとして匿名化する必要がある。

\section{8. まとめと今後の課題}

本研究では先進国における電力供給が社会の生産性を 補完していることを定量的に示し, 電力使用の状況と人 間活動との相関関係を調べることの重要性について述べ た.さらに，電力使用量の状況を建物レベルでモニター することにより建物内の人の移動を単純なエージェント モデルを用いて推計する方法について議論した。

現状では建物内の電力使用量は系統ごとに記録されて おり系統と空間との対応関係を定義して理解するには大 きな規模での設備を必要とする。スマートセンサータッ プを用いた分散型エネルギーマネジメントシステムとセ ンサーネットワークを構築することにより今後局所的な 温度と電力使用量の観測と建物レベルでの大域的な観測 を連動させ，エネルギーマネジメントの精度を向上させ ていくことが期待される。このことを, 経済性を考慮し つつ実現するための電力二次小売システムを提案し，大 阪市咲洲地区での実証実験における測定結果を示した。 さらに, 自然災害発生時における分散型電力供給網の必 
要性を示し, そこで必要とされる機能を本研究で提案し た電力二次小売システムに含めるための仕様の定義につ いて議論した。

本研究において提案するシステムを普及させていくこ とにより, 電力消費の地産地消を可能としつつ, 限られ たエネルギーを効率的に使用することが可能になると期 待される。一方で, その副次的結果として，エネルギー 利用と環境情報および人間活動に関するデータの網羅 的収集が可能となることが期待される。本研究で議論し たシステムでは，今後さらに二つの点について議論が必 要である. (1) 電力と空調 (熱) の連動が行える分散型 $\mathrm{EMS}$ へ拡張することによりコジェネによる 1 次エネル ギーの高効率利用および $(2)$ 自然災害時における分散型 EMS システムの安定的な稼動方法の検討が挙げられる. これは本研究で提案する電力二次小売システムにおいて 大容量バッテリーを搭載し，自然災害発生時または大規 模停電の発生時においても本システムを駆動させること が第一に必要である。また, 近年研究が進められている Energy storage として発展させることが可能であるなら ば，通信回線が切断されたような状況においても，長期 間にわたり孤立系としてのエネルギー供給を継続できる システムが可能と思われる.

分散型 EMS ではスマートセンサータップの開閉およ びセンサー情報の収集などの契約単位の多くの処理を管 理, 監視, 制御する仕組みを個別 EMS 単位で行うエネ ルギーマネジメントシステムを指しているが, 本論文で 提案する分散型 EMS は中央の制御ノードが提示する情 報に基づき協調することを仮定している (Fig. 7(a) 参 照). 今後, ピアツーピア型のアーキテクチャーにより多 数の端末間で通信を行い制御ノードをもたず EMS 間で 協調的に動くアーキテクチャーに本提案システムを発展 させていくことが可能であると考える. この場合, どの ようにして大規模な協調動作を可能とするかについてア ルゴリズムの考案が必要である。この開発は今後重要な 課題となると予想する.

\section{謝 辞}

本研究は環境省平成 24 年度地球温暖化対策技術開発・ 実証研究事業（環境省委託事業）「既設熱源・電源を自 立・分散型エネルギー化し鉄道網を利用した地域融通工 ネルギーシステムの開発事業」の財政的支援を受けて行 われた。本研究を行うにあたり，大阪市立大学中尾正喜 教授, 大阪府立大学横山良平教授, 京都大学大学院工学 研究科引原隆士教授, 京都大学情報学研究科梅野健教授 との議論が有益であった。本研究を実施するにあたり大 阪市環境局北崎元氏と西田壮一氏より協力を賜った。こ こに感謝の意を表する。

\section{参 考文 献}

[1] 世界銀行 World Databank; http://databank.worldbank.org/data/home.aspx

[2] L. Bettencourt, J. Lobo, D. Helbing, C. Kühnert and G. B. West: Growth, innovation, scaling, and the pace of life in cities; Proc. Natl. Acad. Sci. USA, 104 pp. 7301 (2007)

[3] Energy Harvesting Forum; http://www.energyharvesting.net/

[4] F. Cottone, H. Vocca and L. Gammaitoni: Nonlinear energy harvesting; Phys. Rev. Lett., 102, 080601 (2009)

[5] A. Johansson, D. Helbing, H. Z. A-Abideen and S. Al-Bosta: From crowd dynamics to crowd safety: A video-based analysis; Advances in Complex Systems, Vol. 11, No. 4, pp. 497-527 (2008)

[6] M. Davidich and G. Köster : Towards automatic and robust adjustment of human behavioral parameters in a pedestrian stream model to measured data; Safety Science, 50, pp. 1253-1260 (2012)

[7] M. C. González, C. A. Hidalgo and A.-L. Barabáshi: Understanding individual human mobility patterns; Nature, 453, pp. 779-782 (2008)

[8] 東大グリーン ICT プロジェクト (GUTP); http://www.gutp.jp/

[9] NTTファシリティーズクラウド型の BAS およびBEMS のニュースリリース;

http://www.ntt-f.co.jp/news/heisei24/h240201.html (2012 年 2 月 1 日)

[10] サイバーフィジカルシステムとは何か：東京大学 教授 喜連川優氏に聞く;

http://www.sbbit.jp/article/cont1/22970 (2011 年 3 月 10 日)

[11] J. Taneja, R. H. Katz and D. E. Culler: Defining CPS challenges in a sustainable electricity grid; ICCPS, IEEE, pp. 119-128 (2012)

[12] Y. Mo, H.-J. Kim, K. Brancik, D. Dickinson, H. Lee, A. Perrig and B. Sinopoli : CyberPhysical security of a smart grid infrastructure; Proceedings of the IEEE, Vol. 100, No. 1, pp. 195-209 (2012)

[13] F. Schweitzer, G. Fagiolo, D. Sornette, F. VagaRedondo, A. Vespignani and DR. White: Economic networks: The new challenges; Science, Vol. 325, pp. 422-425 (2009)

[14] S. Battiston, D. Delli Gatti, M. Gallegati, B. Greenwald and JE. Stiglitz: Credit chains and bankruptcy propagation in production networks; Journal of Economic Dynamics and Control, Vol. 31, pp. 2061-2084 (2007)

[15] 横山: よりスマートなグリッドの構築に向けて (II); 電 気学会誌, Vol. 130, No. 3, pp. 163-167 (2010)

[16] 相賀, 竹井: 建物のエネルギー使用量推定法に関する研 究 (第 2 報) 事務所ビルにおける夜間の電力消費に関する BEMS データ分析と実測; 空気調和・衛生工学会学術講 
演会講演論文集, 2011(2), pp. 1547-1550 (2011)

[17] 電力小売市場の自由化について;

http://www.enecho.meti.go.jp/denkihp/genjo/ seido.pdf (平成 24 年 4 月)

[18] Y. Susuki, R. Kazaoka and T. Hikihara: Physical architecture and model-based evaluation of electric power system with multiple homes; IEICE Transactions on Fundamentals of Electronics, Communications and Computer Sciences, Vol. E96-A, No. 8 (2013)

[19] A. Castellazzi, T. Takuno, R. Onishi, T. Funaki, T. Kimoto and T. Hikihara: A study of SiC Power BJT performance and robustness; Microelectronics Reliability, Vo. 51, Nos. 9-11, pp. 1773-1777, SeptemberNovember (2011)

[20] 前田, 横畠, 岡部: オンデマンド型電力供給ネットワーク における電力分配アルゴリズムの提案; マルチメディア, 分散, 協調とモバイル (DICOMO2013) シンポジウム, $7 \mathrm{~F}-4$ (2013 年 7 月 12 日)

\section{付録}

\section{付録 1. 時系列分割方法}

$g\left(x, \mu, \sigma^{2}\right)$ を平均 $\mu$, 標準偏差 $\sigma$ の正規分布

$$
g\left(x ; \mu, \sigma^{2}\right)=\frac{1}{\sqrt{2 \pi \sigma^{2}}} \exp \left[-\frac{(x-\mu)^{2}}{2 \sigma^{2}}\right]
$$

とし，与えられたデータ $x_{s} \quad(s=1, \ldots, n)$ を全区間にわ たり正規分布 $g\left(x ; \mu, \sigma^{2}\right)$ からの抽出であると仮定した場 合その尤度は

$$
L_{1}=\prod_{s=1}^{n} g\left(x_{s} ; \mu, \sigma^{2}\right)
$$

で与えられる。一方, 分点 $t$ においてその前後で平均と 分散の異なる二つの正規分布 $g\left(x ; \mu_{L}, \sigma_{L}^{2}\right), g\left(x ; \mu_{R}, \sigma_{R}^{2}\right)$ の混合であると仮定した場合その尤度は

$$
L_{2}(t)=\prod_{s=1}^{t} g\left(x_{s} ; \mu_{L}, \sigma_{L}^{2}\right) \prod_{s=t+1}^{n} g\left(x_{s} ; \mu_{R}, \sigma_{R}^{2}\right)
$$

により与えられる。このふたつの尤度 $L_{1}$ と $L_{2}(t)$ の尤 度比の対数を考える.

$$
\Delta(t)=\log _{e} L_{2}(t)-\log _{e} L_{1}
$$

この尤度比の対数が正の值である場合, $L_{2}(t)$ のモデ ルは $L_{1}$ のモデルよりデータ $x_{s} \quad(s=1, \ldots, n)$ に対して 当てはまりがよいことを意味する。よって $\Delta(t)$ の值に よって時系列を分断するかしないかを決めることがで きる。

この対数尤度比 $\Delta(t)$ は以下にようにして正規分布 $g\left(x ; \mu, \sigma^{2}\right)$ のエントロピー

$$
H\left[g\left(x ; \mu, \sigma^{2}\right)\right]=-\int_{-\infty}^{\infty} g\left(x ; \mu, \sigma^{2}\right) \log _{e} g\left(x ; \mu, \sigma^{2}\right) \mathrm{d} x
$$

によって近似することができる。

$$
\begin{aligned}
\Delta(t) & =\sum_{s=1}^{t} \log _{e} g\left(x_{s} ; \mu_{L}, \sigma_{L}^{2}\right)+\sum_{s=t+1}^{n} \log _{e} g\left(x_{s} ; \mu_{R}, \sigma_{R}^{2}\right) \\
& -\sum_{s=1}^{n} \log _{e} g\left(x_{s} ; \mu, \sigma^{2}\right) \\
& =n H\left[g\left(x ; \mu, \sigma^{2}\right)\right]-t H\left[g\left(x ; \mu_{L}, \sigma_{L}^{2}\right)\right] \\
& -(n-t) H\left[g\left(x ; \mu_{R}, \sigma_{R}^{2}\right)\right]
\end{aligned}
$$

正規分布のエントロピーは

$$
H\left[g\left(x ; \mu, \sigma^{2}\right)\right]=\log _{e} \sigma+\frac{1}{2} \log _{e}(2 \pi e)
$$

によって与えられるので, 結局 $\Delta(t)$ は

$$
\Delta(t)=n \log _{e} \sigma-t \log _{e} \sigma_{L}-(n-t) \log _{e} \sigma_{R}
$$

となる.さらに, パラメータ $\sigma, \sigma_{L}, \sigma_{R}$ を標本標準偏差

$$
\begin{aligned}
\hat{\sigma} & =\sqrt{\frac{1}{n} \sum_{s=1}^{n}\left(x_{s}-\frac{1}{n} \sum_{s^{\prime}=1}^{n} x_{s^{\prime}}\right)^{2}} \\
\hat{\sigma}_{L} & =\sqrt{\frac{1}{t} \sum_{s=1}^{t}\left(x_{s}-\frac{1}{t} \sum_{s^{\prime}=1}^{t} x_{s^{\prime}}\right)^{2}} \\
\hat{\sigma}_{R} & =\sqrt{\frac{1}{n-t} \sum_{s=t+1}^{n}\left(x_{s}-\frac{1}{n-t} \sum_{s^{\prime}=t+1}^{n} x_{s^{\prime}}\right)^{2}}
\end{aligned}
$$

によって近似することにより，

$$
\Delta(t)=n \log _{e} \hat{\sigma}-t \log _{e} \hat{\sigma}_{L}-(n-t) \log _{e} \hat{\sigma}_{R}
$$

により求めることができる。ささらに，もっとも分割する に值する分割点の候補は

$$
t^{*}=\arg \max _{t} \Delta(t)
$$

で与えられる，もし，ある閯值 $\Delta_{c}(>0)$ に対して， $\Delta\left(t^{*}\right)>$ $\Delta_{c}$ となるのであれば時系列の分割を $t^{*}$ で行う.

この分割スキームを再帰的に適用していくことにより， 時系列を複数の性質の異なるセグメントに分断すること が可能である. 


\section{著 者 略 歴}

\section{佐 箭慗彰洋 (正会員)}

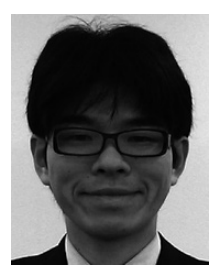

1975 年 1 月 24 日生. 2001 年 3 月東北大 学大学院情報科学研究科システム情報科学 専攻博士後期の課程修了. 同年 4 月京都大 学大学院情報学研究科助手, 2007 年 4 月 同研究科助教となり現在に至る。2010 年 3 月-9 月ドイツ・キール大学経済学部客員 研究員 (平成 21 年度優秀若手研究者海外派遣事業 (常勤研究 者）による），2012 年 10 月-11月スイス・スイス連邦工科大 学チューリッヒ校客員研究員. リスク計測, 不確実環境下で の意思決定, エネルギーマネジメントシステムの研究, デー 夕に基づく経済社会システムの統計分析に従事. 博士（情報 科学). 情報処理学会, 電子情報通信学会, 日本物理学会, 日 本金融・証券計量 - 工学学会, 進化経済学会, 日本統計学会 各正会員.

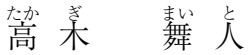

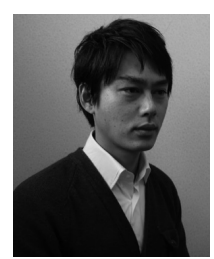

1976 年 10 月 4 日生. 2000 年 3 月京都大 学工学部建築学科卒業. 同年 4 月 (株) 高 松伸建築設計事務所. 2003 年 4 月東京大 学社会基盤工学景観研究室研究生. 2009 年 (株) ダン計画研究所所属. 2012 年大阪 市立大学工学研究科共創研究機構都市工ネ ルギー研究開発センター特任研究員. 2013 年 (株) エナジー シェア設立. 都市計画, 景観設計, スマートコミュニティ計 画策定, 技術開発に従事.

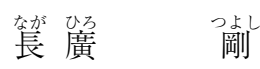

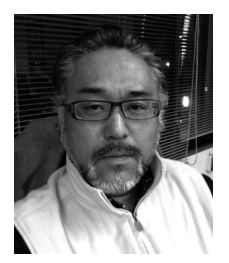

1968 年 1 月 31 日生. 東芝府中工場で発 電所や送電関係に従事, 桜井システムでは 建築設備の設計とエネルギー高効率利用に 関する研究機関の所長を兼務, 阪神大震災 以降，住宅都市整備公団（現 UR）震災復 興本部に出向し，再開発を担当し地域レベ ルでのエネルギーの高効率な利用や都市の在り方などの知見 を深めた。代表作品にアミング潮江（JR 尼崎駅北第二地区 第一種市街地再開発事業），アク夕西宮（西宮北口駅北地区 第二種市街地再開発事業), さらら仁川（仁川駅前地区第一 種市街地再開発事業), ウエルブ六甲道第四地区再開発事業, 1989 年（株）東芝電力システム技術担当，1995 年（株）桜 井システム機械設備副部長, 1996 年住宅都市整備公団, 2000 年 (株) 桜井技術研究所大阪研究所副所長, 2001年 (株) 桜 井エンジニアリング大阪支社副支社長, 2004 年建築機能研 究所 (株) 社長, 2012 年 (株) AFES 大阪支所所長, 2012 年 10 月より大阪市立大学工学研究科共創研究機構都市エネ ルギー研究開発センター特任教授. 建築設備設計, 建築環境, スマートコミュニティ計画策定, 技術開発に従事. 